exempted from military service on medical grounds. His years of school teaching continued until 1930 , with an interlude of nine months in 1922, during which he held a travelling scholarship of the Swedish Academy of Sciences at Göttingen and Munich. During these seventeen years of school teaching, he produced a long series of papers, mainly on gas theory, but also on integral equations, nuclear structure, and radioactivity. His transfer to a university chair seemed rather to bring him new duties than increased leisure, and this, with renewed ill-health, reduced his productivity in his later years, though he continued to think and write on gas theory; one of his last papers was concerned with the absorption of sound in gases and liquids, owing to viscosity and thermal conduction.

Enskog's most distinguished work was done on the kinetic theory of gases ; in his 1917 dissertation, and in a more detailed paper of 1921, he extended Boltzmann's work on entropy and the mean free-path phenomena, solving Boltzmann's integro-differential equation for any moderately rare gas constituted of spherically symmetrical molecules. His exposition was not easy, but his work had great mathematical elegance. The results were substantially the same as those that I had published in 1915 and 1916 , following Maxwell's line of approach. In a subject so complicated it was advantageous to have the two independent treatments, the close agreement of which helped others to have confidence in the results. This work forms the main subject of "The Mathematical Theory of Non-Uniform Gases", by Prof. T. G. Cowling and myself, in which we expounded the theory on his lines rather than on those I had followed; the book was, therefore, appropriately dedicated to Enskog.

Enskog also did important work, yielding valuable results, on the kinetic theory of dense gases and liquids; his interest in this difficult subject was shown over many years. It seems likely, however, that the line of future progress lies along another path, recently opened up by Prof. Max Born and Dr. H. S. Green.

In 1946 the Royal Swedish Academy of Science bestowed on him its Svante Arrhenius Medal, in well-deserved recognition of the distinction of his contributions to gas theory.

Enskog was a friendly man of engaging simplicity and great modesty. His home life was very happy. $\mathrm{He}$ is survived by his wife and children (a son and two daughters) and grandchildren. S. CHAPMAN

\section{Mr. W. H. Pick}

Writ the death of William Henry Pick, a principal seientific officer in the Meteorological Office, which occurred on December 26, 1947, the Meteorological Office and the Royal Air Force lose one who combined to an exceptional degree meteorological and educa. tional ability.

Pick was born in 1891 and after graduating in science at the University of London became a teacher. He showed his interest in meteorology first by maintaining with his pupils at Queen Mary's School, Basingstoke, a climatological station sending returns to the Meteorological Office. He joined the Meteorological Section, Royal Engineers, in 1917, and after serving in France was placed in charge of the meteorological detachment with the North Russian forces in 1919 ; then in 1920 he joined the Meteorological Office. For the next eight years he was meteorological officer at the Royal Air Force College, Cranwell. He wrote for the cadets his book "A Short Course in Meteorology", which soon found appreciation in a much wider circle, edition after edition being called for.

After nearly four years as a senior forecaster at Meteorological Office headquarters, he was meteorological officer at Andover during 1932-38, and in the earlier part of that period was closely and fruitfully associated with twelve special investigations carried out by the R.A.F. into cloud flying with its risks of ice accretion. Advisory duties at H.Q. Bomber Command during 1938-40 were followed, after a short interlude in the Air Ministry, by duties in connexion with the meteorological aspects of smoke screening, first with the Ministry of Home Security and then with H.Q. Anti-Aircraft Command. From early 1945 until a very few days before his untimely end, he was in charge of the meteorological station at South Cerney meeting the requirements of several R.A.F. stations.

Pick wrote numerous papers published by the Meteorological Office or in the Quarterly Journal of the Royal Meteorological Society on visibility as affecting aviation, on the forecasting of night minimum temperatures and the persistence of types of pressure distribution. The thesis "The Teaching of Meteorology in Secondary Schools" for which, with his "Short Course", he was awarded the fellowship of the College of Preceptors particularly exemplifies his two main interests. He served on the council of the Royal Meteorological Society during 1931-36.

Pick will be missed by many members of the Royal Air Force, especially his old Cranwell pupils, to whom he had been a wise teacher and friend, and by his colleagues in meteorological circles. He was married in 1944 and leaves a widow.

\section{Mr. John Lister}

Mr. JoHN Lrster, formerly head of the Mathematical Department, Chelsea Polytechnic, died at Gawsworth, Cheshire, on December 5. Born at Stockport in 1876, he went to the Royal College of Science, London, in 1895, and took his associateship in 1898 with first-class honours in mathematics, physics and chemistry as his main subjects. After two years teaching at West Ham Technical Institute, he was appointed lecturer at Chelsea Polytechnic, where he spent the rest of his teaching career, being eventually head of the Mathematical Department, until his retirement in 1927.

His wide knowledge of cognate subjects gave colour and interest to his teaching of mathematics, and the admirable lucidity of his expositions will be remembered by many generations of Chelsea students.

WE regret to announce the following deaths :

Prof. T. D. A. Cockerell, emeritus professor of zoology, University of Colorado, on January 26, aged eighty-one.

Dr. H. A. Deslandres, For.Mem.R.S., formerly director of the Observatory of Meudon, on January 15 , aged ninety-four.

Mr. Orville Wright, a pioneer with his brother, Wilbur Wright, of the aeroplane, on January 30 , aged seventy-six. 